Mineralogical Journal, Vol. 6, Nos. 1/2, Pp. 36-45, Dec., 1969

\title{
WAIRAKITE-ANALCIME SOLID SOLUTIONS FROM LOW-GRADE METAMORPHIC ROCKS OF THE TANZAWA MOUNTAINS, CENTRAL JAPAN
}

\author{
YOTARO SEKI
}

Department of Foundation Engineering, Saitama University, Urawa

and

YASUE OKI

Hot Spring Research Institute, Kanagawa Prefecture, Odawara

\section{ABSTRACT}

Minerals of intermediate chemical composition between analcime and wairakite are described. They were found in the highest metamorphosed part of the laumontite and mix-layer chlorite zone of the metamorphosed area in the Tanzawa Mountains, central Japan. Chemical analyses and $\mathrm{X}$-ray diffraction studies were carried out on these materials. The results plotted in the Wa-Nat-Ab' diagram indicate that the compositional variation is more extensive than reported in the past. Possible distribution of vacant fields in the diagram is also discussed.

\section{Introduction}

Surdam (1966) noted that wairakites formed in low-grade metamorphic rocks of the Triassic group of Vancouver Island range in their chemical compositions from $\mathrm{NaAlSi}_{2} \mathrm{O}_{6} \cdot \mathrm{H}_{2} \mathrm{O}$ to $\mathrm{CaAl}_{2} \mathrm{Si}_{4} \mathrm{O}_{12}$. $2 \mathrm{H}_{2} \mathrm{O}$ as determined by electron microprobe analyses.

Somewhat analogous minerals of intermediate chemical composition between analcime and wairakite from metamorphosed Tertiary volcanic rocks of the Tanzawa Mountains, central Japan, will be described in some detail in this paper. 
Petrography of some rocks carrying minerals of wairakite-analcime series in the Tanzawa Mountains, Japan

Rocks of the early-middle Miocene Tanzawa group and late Miocene-early Pliocene Ashigara group of the Tanzawa Mountains have been recrystallized under $\mathrm{P}-\mathrm{T}$ conditions of metamorphism ranging from the zeolite facies through the pumpellyite-prehnite and the actinolite-greenschist facies to the amphibolite facies. This metamorphism occurred by down-sinking of a thick ( $>10,000$ meters) pile of submarine volcanic and clastic materials and the intrusion of quartz diorite magma accompanied with lateral migration of the geosynclinal basin during early Miocene to early Pliocene (Seki et al., 1969). The metamorphosed area of the Tanzawa Mountains can be divided into the following five zones based on the occurrence of some metamorphic minerals:

Zone I : Stilbite and vermiculite zone

Zone II : Laumontite and mixed-layer chlorite zone

Zone III : Pumpellyite, prehnite and chlorite zone

Zone IV: Actinolite-greenschist zone

Zone V: Amphibolite zone

Metamorphic rocks containing wairakite or minerals of intermediate chemical composition between wairakite and analcime are found in the highest grade part of Zone II. Petrographical characters of three rocks from which wairakite-analcime series minerals were separated are summarized in Table 1.

Chemical compositions of minerals of the Tanzawa wairakite-analcime series

Three zeolites from the Tanzawa Mountains having intermediate chemical compositions between wairakite and analcime were carefully separated by means of "three-layers heavy-liquid method" (Oki, 1969). As far as observed under the microscope, these separated specimens are completely pure and homogeneous. These three 
Table 1. Petrographical characters of Tanzawa metamorphic rocks bearing minerals of wairakite-analcime series

\begin{tabular}{|c|c|c|c|}
\hline & $\mathrm{T}-1$ (KOH65081511a) & $\mathrm{T}-2$ (KOH65081515a) & $\mathrm{T}-3(\mathrm{KOH} 65081604)$ \\
\hline Original rocks & Basaltic tuff breccia & Basaltic tuff breccia & Andesitic fine-grained tuff \\
\hline $\begin{array}{l}\text { Phenocrysts of } \\
\text { original rocks }\end{array}$ & $\begin{array}{l}\text { Augite (partly replaced by } \\
\text { chlorite and leucoxene) } \\
\text { Plagioclase (partly replaced } \\
\text { by albite, prehnite and } \\
\text { sericite) }\end{array}$ & $\begin{array}{l}\text { Augite (partly replaced by } \\
\text { chlorite and leucoxene) } \\
\text { Plagioclase (partly replaced } \\
\text { by wairakite) }\end{array}$ & $\begin{array}{l}\text { Plagioclase (partly replaced } \\
\text { by laumontite) }\end{array}$ \\
\hline
\end{tabular}


specimens were chemically analysed by a wet method based on an ion-exchange technique (Oki et al., 1962). The analytical results are shown in Table 2 with atomic proportions in terms of anhydrous basis of $\mathrm{O}=96$. Molecular ratios of $\mathrm{Ca}_{8} \mathrm{Al}_{16} \mathrm{Si}_{82} \mathrm{O}_{96}$ (Wa), $\mathrm{Na}_{19.2} \mathrm{Al}_{19.2}$ $\mathrm{Si}_{28.8} \mathrm{O}_{96}$ (Nat), and $\mathrm{Na}_{12} \mathrm{Al}_{12} \mathrm{Si}_{38} \mathrm{O}_{96}\left(\mathrm{Ab}^{\prime}\right)$ of these three minerals are

Table 2. Chemical compositions, atomic ratios and molecular ratios of minerals of wairakite-analcime series from the Tanzawa Mountains, central Japan (Analyst, Y. Oki).

\begin{tabular}{|c|c|c|c|}
\hline & $(\mathrm{KOH} 65081511 \mathrm{a})$ & $\left(\begin{array}{c}\mathrm{T}-2 \\
\mathrm{KOH} 65081515 a)\end{array}\right.$ & $\begin{array}{c}\mathrm{T}-3 \\
(\mathrm{KOH} 65081604)\end{array}$ \\
\hline $\mathrm{SiO}_{2}$ & 57.07 & 56.27 & 57.41 \\
\hline $\mathrm{TiO}_{2}$ & 0.00 & $\operatorname{tr}$. & 0.00 \\
\hline $\mathrm{Al}_{2} \mathrm{O}_{3}$ & 20.64 & 21.32 & 20.11 \\
\hline $\mathrm{Fe}_{2} \mathrm{O}_{3}$ & 0.48 & n.d. & n.d. \\
\hline $\mathrm{FeO}$ & $\operatorname{tr}$ & n.d. & n.d. \\
\hline $\mathrm{MnO}$ & n.d. & n.d. & 0.00 \\
\hline $\mathrm{MgO}$ & 0.04 & 0.43 & 0.70 \\
\hline $\mathrm{CaO}$ & 8.30 & 6.17 & 1. 42 \\
\hline $\mathrm{Na}_{2} \mathrm{O}$ & 4.14 & 6.57 & 10.79 \\
\hline $\mathrm{K}_{2} \mathrm{O}$ & 0.14 & 0.17 & 0.07 \\
\hline $\mathrm{H}_{2} \mathrm{O}^{+}$ & 9.20 & 8.88 & 8.87 \\
\hline $\mathrm{H}_{2} \mathrm{O}^{-}$ & 0.23 & 0.06 & 0.17 \\
\hline Total & 100.24 & 99.87 & 99.54 \\
\hline $\mathrm{O}$ & 96.00 & 96.00 & 96.00 \\
\hline $\mathrm{Si}$ & 33.33 & 32.87 & 33.64 \\
\hline Al & 14.40 & 14.79 & 14.01 \\
\hline $\mathrm{Fe}^{\prime \prime \prime}$ & 0.20 & - & - \\
\hline $\mathrm{Mg}$ & 0.04 & 0.38 & 0.62 \\
\hline $\mathrm{Ca}$ & 5. 26 & 3.89 & 0.90 \\
\hline $\mathrm{Na}$ & 4.75 & 7.50 & 12.36 \\
\hline $\mathrm{K}$ & 0.11 & 0.13 & 0.05 \\
\hline $\mathrm{H}_{2} \mathrm{O}$ & 18. 18 & 17.44 & 17.50 \\
\hline $\mathrm{Ca}_{8} \mathrm{Al}_{16} \mathrm{Si}_{32} \mathrm{O}_{96}$ (Wa) & 66 & 49 & 11 \\
\hline $\mathrm{Na}_{19.2} \mathrm{Al}_{19.2} \mathrm{Si}_{28.8} \mathrm{O}_{96}$ (Nat) & 0 & 11 & 19 \\
\hline $\mathrm{Na}_{12} \mathrm{Al}_{12} \mathrm{Si}_{36} \mathrm{O}_{96}\left(\mathrm{Ab}^{\prime}\right)$ & 34 & 40 & 70 \\
\hline
\end{tabular}


Table 3. X-ray powder diffraction data, optical properties

\begin{tabular}{|c|c|c|c|c|}
\hline \multirow[t]{2}{*}{$h k l$} & \multicolumn{2}{|l|}{ A } & \multicolumn{2}{|c|}{$B(T-1)$} \\
\hline & $2 \theta(\mathrm{CuK} \alpha)$ & $I$ & $2 \theta(\mathrm{CuK} \alpha)$ & $I$ \\
\hline 200 & $13.0^{\circ}$ & 37 & $13.0^{\circ}$ & 10 \\
\hline 211 & 15.9 & 100 & 15.9 & 50 \\
\hline 220 & 18. 4 & 30 & 18.4 & 21 \\
\hline 321 & 24.46 & 23 & 24.45 & 10 \\
\hline 400 & 26.10 & 100 & 26.10 & 100 \\
\hline 004 & 26.27 & 100 & 26.22 & 100 \\
\hline 332 & 30.80 & 33 & 30.77 & 52 \\
\hline 422 & 32.20 & 9 & 32.17 & 7 \\
\hline 431 & 33.46 & 16 & 33.46 & 18 \\
\hline 521 & 36.08 & 17 & 36.05 & 16 \\
\hline 440 & 37.23 & 11 & 37.23 & 16 \\
\hline 611 & 40.70 & 13 & 40.70 & 10 \\
\hline 543 & 47.10 & 4 & 47.02 & 4 \\
\hline 640 & 48.06 & 10 & 48.00 & 11 \\
\hline 552 & 49.06 & 9 & 48.97 & 9 \\
\hline 732 & 52.80 & 17 & 52.76 & 17 \\
\hline 800 & 53.69 & 6 & 53.69 & 5 \\
\hline 831 & 58.07 & 7 & 58.06 & 8 \\
\hline $\begin{array}{l}\text { Falrea peaks of } 332 \text {, } \\
332: 431, \overline{4} 31: 521, \overline{5} 21\end{array}$ & \multicolumn{2}{|c|}{ clearly observed } & \multicolumn{2}{|l|}{ observed } \\
\hline Refractive indices & \multicolumn{2}{|c|}{$\begin{array}{l}\alpha=1.498 \pm 0.001 \\
\beta=1.502 \pm 0.001\end{array}$} & \multicolumn{2}{|c|}{$n_{\max }=1.499 \pm 0.001$} \\
\hline Double refraction & \multicolumn{2}{|l|}{ anisotropic } & \multicolumn{2}{|l|}{ anisotropic } \\
\hline Crossed lamellar twin & \multicolumn{2}{|c|}{ clearly observed } & \multicolumn{2}{|c|}{ clearly observed } \\
\hline Unit-cell dimensions & \multicolumn{2}{|l|}{$\begin{array}{l}a=13.65 \AA \\
b=13.66 \\
c=13.56 \\
\beta=90^{\circ} 23^{\prime}\end{array}$} & \multicolumn{2}{|l|}{$\begin{array}{l}a=13.66 \AA \\
b=13.66 \\
c=13.58 \\
\beta=90^{\circ} 20^{\prime}\end{array}$} \\
\hline Density & \multicolumn{2}{|c|}{$2.26_{5}$} & \multicolumn{2}{|c|}{$2.26_{0}$} \\
\hline
\end{tabular}

A: Wairakite from Katayama geothermal area, Onikobe, Japan. Bore-hole core GO-7, $397.64 \mathrm{~m}$ (Seki et al., 1969).

B: Wairakite from Tanzawa Mountains. T-1. 
and densities of minerals of wairakite-analcime series.

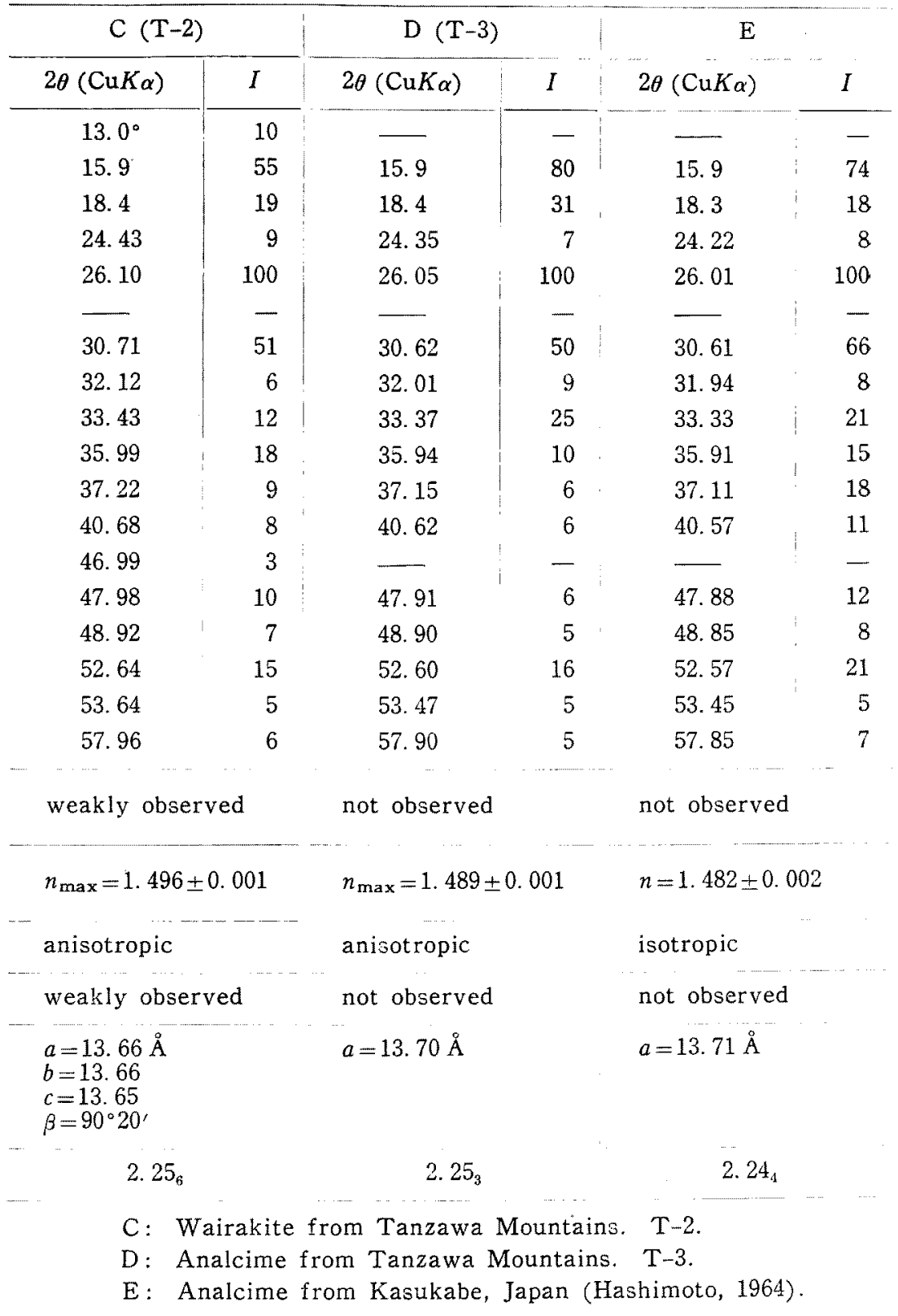


also shown in Table 2.

$X$-ray powder data, unit-cell dimensions, optical properties and densities

Table 3 summarizes $\mathrm{X}$-ray powder diffraction data, until-cell dimensions calculated therefrom, optical properties and densities of the minerals of wairakite-analcime series from the Tanzawa Mountains, a wairakite from the Onikobe geothermal area and an analcime from Kasukabe, Japan.

From Table 3 , it is clear that the investigated Tanzawa minerals are intermediate with regard to $X$-ray diffraction, unit-cell dimensions and optical properties between wairakite and analcime. $T-1$ is clearly monoclinic, but the $c$ dimension of $T-2$ is practically the same as $a$ and $b$ of the same mineral and separation of the $\overline{3} 32$ peak from 332 is indistinct. Probably the mineral $\mathrm{T}-2$ is monoclinic but its monoclinicity obviously is very small.

As far as observed from X-ray powder data and optical properties the mineral $T-3$ must be cubic or pseudocubic, but not monoclinic.

Refringence and density decrease in the order of $T-1, T-2$ and $T-3$, correlating with the decrease of the $\mathrm{Wa}$ end member in these materials.

\section{Considerations}

Starting with glasses, Saha $(1959,1961)$ synthesized analcimes having a wide composition range from $\mathrm{NaAlSi}_{1.5} \mathrm{O}_{5} \cdot 0.75 \mathrm{H}_{2} \mathrm{O}$ through $\mathrm{NaAlSi}_{2} \mathrm{O}_{6} \cdot \mathrm{H}_{2} \mathrm{O}$ (ideal form of analcime) to $\mathrm{NaAlSi}_{3} \mathrm{O}_{8} \cdot 1.5 \mathrm{H}_{2} \mathrm{O}$. He showed that the variation of water contents and unit-cell constants are linear functions of the silica contents of the analcimes. Natural analcimes also have a wide range of chemical compositions from stoichiometric analcime to a composition very close to $\mathrm{NaAlSi}_{3} \mathrm{O}_{8}$. $1.5 \mathrm{H}_{2} \mathrm{O}$. Saha also found that the difference $2 \theta_{\text {Analcime (639) }}-2 \theta_{\text {Silicon (331) }}$ ( $\mathrm{C} \mathrm{K} K \alpha$ radiation) can be used to determine the substitution of $\mathrm{NaAl}$ for $\mathrm{Si}$ in analcime solid solutions. 
Ross (1928, 1941), Wilkinson (1963) and Wilkinson and Whetten (1964) have demonstrated a wide range of chemical composition for analcimes formed in a basaltic lava sequence and in pyroclastic and sedimentary piles. Recently Coombs and Whetten (1967), from data for unit-cell sizes of analcimes, showed that analcimes from sedimentary and burial metamorphic rocks range in chemical composition from $\mathrm{Na}_{16} \mathrm{Al}_{18} \mathrm{Si}_{32} \mathrm{O}_{96} \cdot 16 \mathrm{H}_{2} \mathrm{O}$ to $\mathrm{Na}_{13} \mathrm{Al}_{13} \mathrm{Si}_{85} \mathrm{O}_{96} \cdot n \mathrm{H}_{2} \mathrm{O}$.

Steiner (1955) and Coombs (1955) who first reported the occurrence and mineralogical properties of wairakite suggested that isomorphous substitution between analcime and wairakite is very limited due to structural differences between these two end members.

The compositions of wairakites described in this paper and those of wairakites and analcimes from the literature are plotted in Fig. 1. Evidently $\mathrm{Na}_{19.2} \mathrm{Al}_{19.2} \mathrm{Si}_{28.8} \mathrm{O}_{96} \cdot m \mathrm{H}_{2} \mathrm{O}$ (Nat in Fig. 1) and $\mathrm{Na}_{12} \mathrm{Al}_{12}$ $\mathrm{Si}_{36} \mathrm{O}_{96} \cdot n \mathrm{H}_{2} \mathrm{O}\left(\mathrm{Ab}^{\prime}\right.$ in Fig. 1) form a continuous solid solution nature.

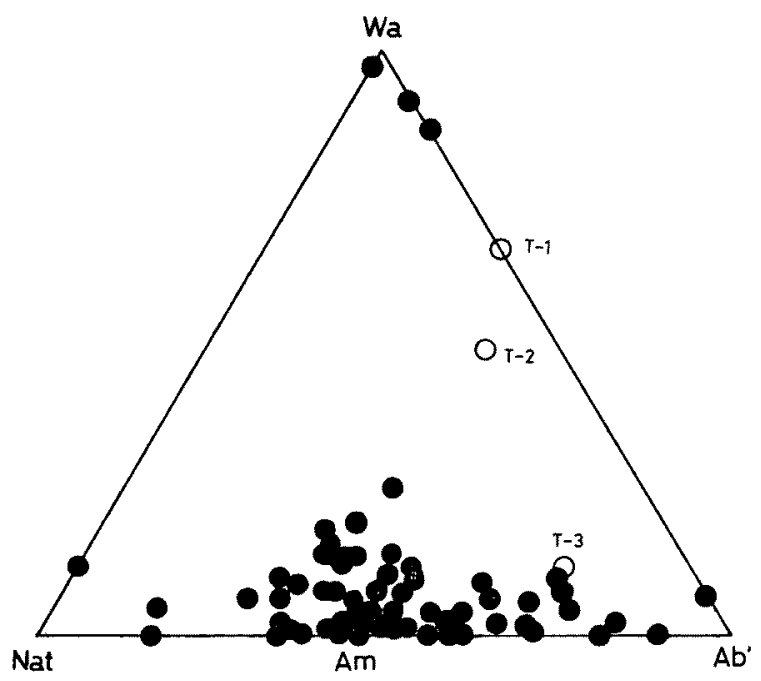

Fig. 1. Plot of wairakites and analcimes in a $\mathrm{Ca}_{8} \mathrm{Al}_{16} \mathrm{Si}_{32} \mathrm{O}_{96}$. $p \mathrm{H}_{2} \mathrm{O}$ (Wa) $-\mathrm{Na}_{19.2} \mathrm{Al}_{19.2} \mathrm{Si}_{28.8} \mathrm{O}_{96} \cdot m \mathrm{H}_{2} \mathrm{O}$ (Nat) $-\mathrm{Na}_{12} \mathrm{Al}_{12} \mathrm{Si}_{36} \mathrm{O}_{96} \cdot n \mathrm{H}_{2} \mathrm{O}$ $\left(\mathrm{Ab}^{\prime}\right)$ diagram. Open circles are minerals described in this paper, and black circles from literatures. 
We have no conclusive data, however, to indicate the presence of complete solid solution between $\mathrm{Ca}_{8} \mathrm{Al}_{16} \mathrm{Si}_{32} \mathrm{O}_{96} \cdot p \mathrm{H}_{2} \mathrm{O}$ (Wa in Fig. 1) and the other two end members. Notes presented by Coombs and others (1959) and by Surdam (1966) are incomplete to demonstrate complete solid solution between $\mathrm{Nat}$ and $\mathrm{Wa}, \mathrm{Ab}^{\prime}$ and $\mathrm{Wa}$, and $\mathrm{Na}_{16}$ $\mathrm{Al}_{16} \mathrm{Si}_{82} \mathrm{O}_{96} \cdot q \mathrm{H}_{2} \mathrm{O}$ (Am in Fig. 1) and Wa.

From the data presented in Fig. 1, two types of vacant field in the system of Wa-Nat-Ab' can be anticipated as shown in Fig. 2.
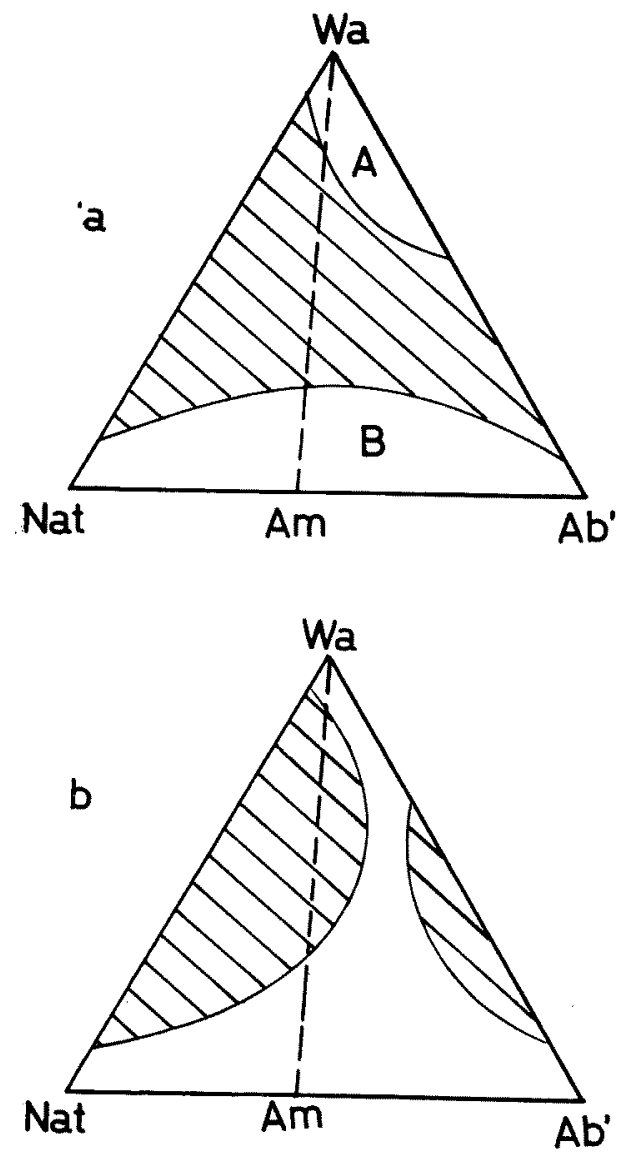

Fig. 2. Probable vacant fields (hatched areas) in the Wa.Nat.Ab' system.
If Fig. 2a is correct, minerals which lie within field $A$ are monoclinic but those having compositions within field $B$ are cubic or pseudocubic. Monoclinicity of minerals in field A generally becomes less conspicuous with the decrease of the Wa component and the increase of the $\mathrm{Ab}^{\prime}$ and/or Nat compositions. However, if Fig. 2b is accepted, the cubic or pseudocubic symmetry of Nat-Ab' solid solution must be gradually distorted into a monoclinic one with the increase of the Wa molecule. In either case of Figs. $2 a$ and $2 b$, there will be a wide vacant immiscibility area between the wairakite composition and $\mathrm{Na}_{16} \mathrm{Al}_{15} \mathrm{Si}_{32}$ $\mathrm{O}_{96} \cdot q \mathrm{H}_{2} \mathrm{O}$ (ideal composition of analcime, Am).

Three new analyses in 
this paper indicate the compositional variation is more extensive than reported in the past. However, unless we can demonstrate equilibrium between a sodic wairakite and a calcic analcime which coexist, the presence of a solvus in the $\mathrm{Wa}-\mathrm{Ab}^{\prime}$-Nat system as shown in Fig. 2a can not be completely proved. Further study of natural minerals of wairakite-analcime series as well as more detailed experimental work of the Wa-Ab'-Nat system are necessary to throw more light on this problem.

The present writers thank Dr. W. G. Ernst and Dr. J.G. Liou of the Department of Geology, University of California, Los Angeles for their helpful advice and critically reading this manuscript.

\section{REFERENCES}

Coombs, D.S. (1955). Min. Mag., 30, 699.

Coombs, D.S., Ellis, A.J., Fyfe, W.S. \& Taylor, A.M. (1959). Geoch. et Cosmoch. Acta, 17, 53.

Coombs, D.S. \& Whetten, J.T. (1967). Geol. Soc. Amer. Bull., 78, 269. Hashimoto, M. (1964). J. Geol. Soc. Japan, 70, 227.

Oki, Y. (1969). In preparation.

Oki, Y., Oki, S. \& Shibata, H. (1962). Bull. Chem. Soc. Jap., 35, 273.

Ross, C.S. (1928). Amer. Min., 13, 195.

Ross, C.S. (1941). Amer. Min., 26, 627.

Saha, P. (1959). Amer. Min., 44, 300.

Saha, P. (1961). Amer. Min., 46, 859.

Seki, Y., Oki, Y., Matsuda, T., Mikami, K. \& Okumura, K. (1969). Journ. Assoc. Jap. Min. Petr. Economic Geol., 61, 1 \& 50.

Steiner, A. (1955). Min. Mag., 30, 691.

Surdam, R.C. (1966). Geol. Soc. Amer. Special Paper, 87, 169.

Wilkinson, J.F.G. (1963). Min. Mag., 33, 498.

Wilkinson, J.F.G. \& Whetten, J.T. (1964). J. Sed. Petr. 34, 543.

Manuscript received 8 May 1969. 